\title{
PLANNING MATRIX SEBAGAI UPAYA PENINGKATAN MUTU PELAYANAN RAWAT INAP DI RUMAH SAKIT UMUM BHAKTI RAHAYU SURABAYA
}

\author{
PLANNING MATRIX IN AN EFFORT TO INCREASE THE QUALITY OF SERVICE OF INPATIENT \\ CARE IN GENERAL HOSPITAL BHAKTI RAHAYU SURABAYA \\ Ika Avrianti \\ Fakultas Kesehatan Masyarakat, Universitas Airlangga Surabaya \\ E-mail:iniemailafree8@gmail.com
}

\begin{abstract}
Inpatient unit of Bhakti Rahayu Hospital as one potential revenue center for the hospital expected to be able to support an increas the income of the hospital. The issue of this research is the decrease trend of Bed Occupancy rate $48,96 \%$ with trend $-15,79 \%$. This research aims to increas the quality of inpatient services care in Bhakti Rahayu Hospital based on planning matrix. This research was in inpatient unit Bhakti Rahayu Hospital with an descriptive design cross sectional study of the 80 patients who are representing inpatient hospitalization were taken by simple random sampling. Data was collected by using questionnaires distributed to patients and analysed by quantitative methods arranged in the planning matrix table. The results showed that inpatient services quality has not met the standards of good service so that the service implementation need improvement and enhancement services primarily on aspects of the physical and human resources. The conclusions showed that to increase the quality of health care based on internal factors was very important. Physical aspects and human resources are the top priority to fix up.
\end{abstract}

Keywords:services quality, planning matrix, inpatient unit

\section{PENDAHULUAN}

Rumah sakit sebagai salah satu penyelenggara pelayanan kesehatan memiliki peran yang sangat strategis dalam mempercepat peningkatan derajat kesehatan masyarakat yang setinggi-tingginya (Undang-Undang nomor 44 tahun 2009 tentang rumah sakit pasal 1 ayat 1$)$.

Peran strategis ini didapat karena rumah sakit merupakan fasilitas pelayanan kesehatan yang padat karya. Peran tersebut pada dewasa ini semakin menonjol mengingat perkembangan pola penyakit yang beragam serta peningkatan perubahan struktur sosial ekonomi masyarakat dan pelayanan yang menuntut adanya pelayanan kesehatan yang lebih bermutu, ramah dan sanggup memenuhi kebutuhan mereka yang menuntut perubahan pola pelayanan kesehatan di Indonesia (Aditama, 2003).

Rumah sakit merupakan usaha pelayanan jasa kesehatan dimana masalah kualitas pelayanan, kepuasan dan loyalitas pasien menjadi faktor utama dalam menentukan keberhasilan rumah sakit. Selain itu, rumah sakit harus memiliki keunggulan dan kelengkapan fasilitas serta sikap dan layanan sumber daya manusia yang merupakan subdimensi yang berpengaruh secara signifikan terhadap pelayanan yang diberikan dan dipersepsikan pasien. Rumah sakit akan kehilangan banyak pasien dan dijauhi apabila mengabaikan sub-dimensi tersebut.

Ditengahpersaingan industri jasa perumahsakitan yang semakin ketat, sebuah rumah sakit dituntut untuk memberikan pelayanan yang semakin prima dengan meningkatkan mutu pelayanan. Peningkatan mutu pelayanan dilakukan melalui profesionalisme manajemen unit kerja yang 
potensial dengan memberikan pelayanan yang sesuai dengan harapan pasien sehingga akan memberikan kepuasan keada pasien. Unit kerja yang potensial diantaranya adalah rawat inap, rawat jalan, unit gawat darurat, instalasi farmasi, dan sebagainya.

Instalasi rawat inap merupakan salah satu potential revenue center bagi rumah sakit. Setiap tahun, rawat inap memberikan kontribusi yang cukup signifikan bagi rumah sakit sehingga pengelolaannya harus dilakukan secara serius (Arianto,2011).
Rumah sakit sebagai industri jasa kesehatan yang padat modal dan padat karya, mau tidak mau rumah sakit harus selalu berusaha meningkatkan pendapatannya. Dengan demikian, rumah sakit bisa melakukan perbaikan kesejahteraan karyawan dan pengembangan rumah sakit.

Salah satu bentuk penilaian terhadap kinerja Unit Rawat Inap Rumah Sakit Umum Bhakti Rahayu Surabaya yakni berdasarkan BOR, ALOS, BTO, dan TOI yang disajikan pada Tabel 1.

Tabel 1 Jumlah Tempat Tidur dan Indikator Kinerja Rumah Sakit di Rumah Sakit Umum Bhakti Rahayu tahun 2011-2014

\begin{tabular}{lcccc}
\hline \multicolumn{1}{c}{ Atribut } & \multicolumn{3}{c}{ Tahun } \\
\cline { 2 - 5 } & $\mathbf{2 0 1 1}$ & $\mathbf{2 0 1 2}$ & $\mathbf{2 0 1 3}$ & $\mathbf{2 0 1 4}$ \\
\hline Jumlah TT & 150 & 150 & 134 & 134 \\
BOR (\%) & 44,41 & 46,86 & 56,69 & 48,96 \\
Trend (\%) & - & 5,23 & 17,34 & $-15,79$ \\
Standar ideal BOR * & $60-85$ & $60-85$ & $60-85$ & $60-85$ \\
Pergerakan BOR & - & naik & Naik & turun \\
ALOS (hari) & 4,02 & 4,17 & 4,34 & 4,28 \\
Standar ideal ALOS * & $6-9$ hari & $6-9$ hari & $6-9$ hari & $6-9$ hari \\
BTO & 40,34 & 41,00 & 47,72 & 41,73 \\
Standar ideal BTO * & $40-50$ & $40-50$ & $40-50$ & $40-50$ \\
TOI & 5,03 & 4,73 & 3,31 & 4,46 \\
Standar ideal TOI* & $1-3$ hari & $1-3$ hari & $1-3$ hari & $1-3$ hari \\
\hline
\end{tabular}

Sumber: Laporan Tahunan Rumah Sakit Umum Bhakti Rahayu Surabaya Tahun 2010 s.d 2014

Berdasarkan Tabel 1, dapat diketahuibahwa nilai BOR Rumah Sakit Bhakti Rahayu Surabaya berkisar antara $44,41 \%$ sampai 48,96\% pada tahun 2011 sampai 2014 dan selalu lebih rendah dibandingkan standaridealBOR menurut Kementrian Kesehatan yakni sebesar $60-85 \%$ (Depkes RI, 2005).Nilai BOR sempat mengalami kenaikan sebesar 2,45\% dari tahun 2011 menuju 2012 dan mengalami kenaikan yang cukup signifikan pada tahun 2012 menuju 2013 yaitu sebesar 9,8\%. Namun pada tahun 2014 nilai BOR hanya sebesar
$48,96 \%$ dengan tren sebesar $-15,79 \%$ dibandingkan dengan tahun 2013.

Data ALOS cenderung normal akan tetapi ALOS yang normal bukan berarti mutu pelayanan baik karena masih tergantung nilai indikator yang lain. Berdasarkan indikator BTO, rumah sakit masih normal yakni berkisar pada angka 40-47, artinya selama 1 tahun tempat tidur diisi hanya 40-47 kali. Namun hal ini tidak menjadi masalah mengingat angka ALOS yang rendah. Apabila dilihat dari nilai TOI maka rumah sakit melebihi standar ideal 1-3 hari sehingga akan cukup menyebabkan masalah 
dikarenakan rata-rata TT kosong selama3-5 hari setelah pasien keluar.

Permasalahan yang diangkat pada penelitian ini adalah rendahnya nilai BOR sebesar $48,96 \%$ dengan trend sebesar $-15,79 \%$ di Unit Rawat Inap Rumah Sakit Umum Bhakti Rahayu Surabaya tahun 2014. Tujuan dari penelitian adalah menyusun planning matrix sebagai upaya peningkatan mutu pelayanan rawat inap di Rumah Sakit Umum Bhakti Rahayu Surabaya. Planning matrix merupakan metode yang memuat data kuantitatif mengenai kebutuhan pelanggan, dimana digunakan untuk membantu tim pelaksana dalammemutuskan aspek mana saja yang akan difokuskan selama proses pengembangan organisasi yang sedang berlangsung (Cohen, 1995), hal tersebut sangat bermanfaat dalam penyusunan strategi rumah sakit untuk meningkatkan mutu pelayanan.

\section{PUSTAKA}

\section{Planning Matrix}

Planning matrix yang merupakan bagian dari house of quality adalah alat untuk membantu tim pengembangan dalam memprioritaskan kebutuhan dan harapan pelanggan. Planning matrix mencatat masing-masing kebutuhan atau keuntungan dari produk atau jasa yang ditawarkan kepada pelanggan berdasarkan interpretasi tim pengembang dan data hasil penelitian. Planning matrixterdiri dari 8 bagian yaitu: 1) tingkat kepentingan pelanggan (important to customer), 2) tingkat kepuasan pelanggan (customer satisfaction performance), 3)goal dan improvement ratio, 4)sales point, 5) raw weight, 6) normalized raw weight, 7) cummulative normalized raw weight, dan 8) completed planning matrix. Adapun 8 bagian planningmatrixtersebut dijelaskan sebagai berikut:

Tingkat kepentingan pelanggan (important to customer) terdiri dari kolom tingkat kepentingan yang merupakan tempat dimana hasil pengambilan data mengenai seberapa penting kebutuhan pada suatu atribut pelayanan. Tingkat kepentingan diukur dengan membagikan kuesioner kepada pelanggganyang memuat uraian kebutuhan pelanggan pada setiap atribut pelayanan.Pada analisis hasil akhir, uraian kebutuhan pelanggan yang memiliki tingkat kepentingan tinggi akan direspon oleh penyedia jasa sebagai respon teknik.Tingkat kepentingan atribut (importance to customers) dan customer satisfaction performance diperoleh bersamaan dengan informasi kebutuhan dan harapan pelanggan diawal proses.

Tingkat kepuasan pelanggan (customer satisfaction performance)merupakan persepsi pelanggan mengenai seberapa baik suatu produk atau layanan dapat memenuhi kebutuhan pelanggan. Penilaian tingkat kepuasan pelanggan (customer satisfaction performance) pada masingmasing atribut pelayanan merupakan nilai rerata komposit dari penilaian individu pasien.

Goal atau tujuan merupakan penentuan tingkat kepuasan yang ingin dicapai untuk setiap keinginan dan kebutuhan pelanggan, nilainya ditentukan oleh pemberi pelayanan. Skala goal mengikuti skala dari rating 1 sampai 5 , sedangkan rasio perbaikan (improvement ratio) adalah tujuan kepuasan pelanggan pada prespektif pengguna 
jasa. Secara matematis, dalam Cohen (1995) dirumuskan sebagai berikut:

Improvement Ratio $=\frac{\operatorname{Goal}(\mathrm{G})}{\text { Customer Satisfaction Performance }(\mathrm{CSP})}$

Improvement ratio menurut skala Cohen

(1995), dapat diklasifikasikan dalam empat kategori yaitu:

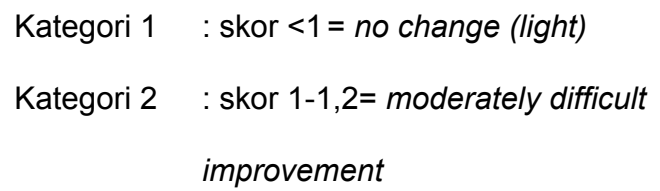

Kategori 3 : skor 1,2-1,5= difficult Improvement

Kategori 4 : skor $>1,5=$ very difficult improvement

Semakin besar kategori menunjukkan semakin berat upaya perbaikan yang harus dilakukan oleh organisasi untuk mencapai tujuan (goal) yang ditetapkan.

Sales pointadalah nilai jual yang dimiliki oleh sebuah produk berdasarkan seberapa baik kebutuhan pelanggan terpenuhi. Sales point ditentukan oleh pihak organisasi. Nilai mencerminkan tingkat kepentingan yang dapat diperoleh apabila dilakukan kepentingan perbaikan dan penyempurnaan indikator. Sales pointmempunyai nilai dari salah satu diantara tiga nilai berikut:

$$
\begin{array}{ll}
1 & =\text { no sales point } \\
1,2 & =\text { medium sales point } \\
1,5 & =\text { strong sales point }
\end{array}
$$

Raw weight merupakan nilai penjumlahan dari data dan merupakan keputusan yang dibuat dalam kolom planning matrix di sebelah kiri (Cohen,
1995). Secara matematis dapat dirumuskan sebagai berikut:

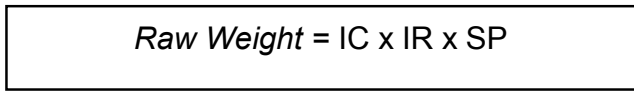

Semakin tinggi nilai raw weight, maka semakin penting customer need tersebut. Raw weight menyediakan strategi bisnis secara menyeluruh pada tingkat kepentingan dari customer need kepada kesuksesan produk atau jasa yang direncanakan.

Normalized raw weight adalah skala 0-1 atau dinyatakan dalam suatu persentase (Cohen, 1995). Penghitungan nilainormalized raw weightdilakukan dengan menghitung total raw weight kemudian dihitung normalized raw weight tiap kebutuhan konsumen dengan rumus sebagai berikut:

Normalized Raw Weight $=\frac{\text { Raw Weight }(R W)}{\text { Total Raw Weight }(\mathrm{TRW})}$

Cumulative normalized raw weight ditempatkan paling akhir dan paling kanan dalam planning matrix (Cohen, 1995). Cumulative normalized raw weight digunakan untuk mengetahui kebutuhan konsumen yang paling penting. Cumulative normalized raw weight memperlihatkan seberapa besar total raw weight sehingga dapat menentukan kebutuhan konsumen terhadap produk atau jasa yang paling penting.

Completed planning matrix atau gabungan matriks perencanaan merupakan hasil dari riset pasar yang ditampilkan dalam sebuah tabel yang menjadi dasar keputusan dalam melakukan strategi pemasaran yang lebih efektif dalam mencapai 
kepentingan dan kepuasan konsumen terhadap jasa yang diberikan oleh penyedia pelayanan.

\section{METODE}

Penelitian ini termasuk penelitian deskriptif dengan menggunakan rancang bangun cross sectional. Penelitian ini dilaksanakan pada bulan November tahun 2015-April tahun 2016 di Rumah Sakit Umum Bhakti Rahayu Surabaya.

Penelitian ini menggunakan dua jenis populasi yaitu seluruh pasien yang menggunakan pelayanan rawat inap di Rumah Sakit Umum Bhakti Rahayu Surabaya sebesar 475 pasien yang diperoleh dari rata-rata jumlah pasien tiap bulan pada tahun 2014 dan seluruh petugas manajemen rawat inap Rumah Sakit Umum Bhakti Rahayu Surabaya yang terlibat langsung dalam proses pelayanan rawat inap.

Sampel dalam penelitian ini terbagi menjadi sampel pasien dan sampel petugas manajemen rawat inap. Sampel pasien diperoleh dengan menggunakan teknik simple random sampling dengan jumlah sebesar 80 pasien. Sampel petugas manajemen rawat inap diperoleh dengan menggunakan total populasi penelitian yaitu kepala perawat,seluruh ketua unit dan penanggung jawab ruang rawat inap sejumlah 30 orang.

Teknik dan instrumen pengumpulan data menggunakan kuesioner yang diberikan kepada masyarakat pengguna layanan rawat inap yang berisi tentangtingkat kepentingan dan tingkat kepuasan pasien terhadap pelayanan rawat inap
Rumah Sakit Umum Bhakti Rahayu Surabaya.

Lembar pengisian skoring digunakan untuk menentukan tujuan (goal) dan nilai jual (sales point) yang diisi oleh petugas manajemen rawat inap di Rumah Sakit Umum Bhakti Rahayu Surabaya.

Teknik analisis data dalam penelitian ini menggunakan metode planning matrix yaitu dengan menganalisis data tingkat kepentingan dan tingkat kepuasan pasien atau customer satisfaction performance diperoleh dari meanatau rata-ratapada setiap atribut. Data tingkat kepentingan diambil modusnya kemudian diberi skor sesuai nilai modus. Selanjutnya, menganalisis goal dan sales pointyang hasilnya diperoleh dari pengumpulan data pasien.Sedangkan improvement ratio diperoleh dari goal dibagi dengan kepuasan pelanggan atau customer satisfaction performance.

Hasil improvement ratio dipergunakan untuk menganalisis berat atau ringannya tiap permasalahan yang harus diselesaikan. Kemudian melakukan perhitungan antara unsur dalam planning matrix tercantum dalam hasil raw weight $(R W)$, normalized raw weight (NRW), dan cumulative normalized raw weight (CNRW). Hasil analisis data disusun dalam tabel planning matrix.

\section{HASIL dan PEMBAHASAN}

Tingkat Kepentingan Pasien Terhadap Pelayanan Rawat Inap di Rumah Sakit Umum Bhakti Rahayu Surabaya

Tingkat kepentingantertinggi pasien terhadap pelayanan rawat inap di Rumah Sakit Umum Bhakti Rahayu Surabaya disajikan pada Tabel 2. 
Tabel 2 Uraian Kepentingan Tertinggi PasienTerhadap Atribut Pelayanan Rawat Inap Rumah Sakit Umum Bhakti Rahayu Surabaya Tahun 2016

\begin{tabular}{|c|c|}
\hline \multirow{2}{*}{$\begin{array}{c}\text { Atribut } \\
\text { Pelayanan }\end{array}$} & \multirow{2}{*}{$\begin{array}{c}\text { Uraian } \\
\text { Kepentinqan Tertingqi }\end{array}$} \\
\hline & \\
\hline $\begin{array}{l}\text { Layanan Penerimaan } \\
\text { pasien/UGD }\end{array}$ & Petugas melayani pasien dengan sopan, ramah dan tanggap \\
\hline Ruang Rawat Inap & Ruang rawat inap tertata rapi, bersih, tenang, aman dan nyaman \\
\hline Dokter & $\begin{array}{l}\text { Dokter tersedia dalam } 24 \text { jam dan dokter yang menangani pasien selalu on } \\
\text { call }\end{array}$ \\
\hline Perawat & Perawat memperhatikan kebutuhan dan keluhan pasien \\
\hline Farmasi & Petugas melayani dengan sopan, ramah, dan tanggap \\
\hline Gizi & $\begin{array}{l}\text { Petugas memberi informasi mengenai menu yang tersedia dan menanyakan } \\
\text { kecukupan dan rasa makanan serta makanan yang disukai atau tidak } \\
\text { disukai pasien }\end{array}$ \\
\hline Administrasi Keuangan & Penyediaan fasilitas pembayaran non tunai (debet) \\
\hline
\end{tabular}

Hasil penelitian menunjukkan bahwa sebagian besar kepentingan tertinggi pasien adalah pada aspek kualitas fungsional (functional quality) terkait proses menyampaikan pelayanan, bagaimana petugas dapat melayani pasien dengan baik serta kenyamanan. Kepentingan tertinggi yang dinilai pasien sangat penting agar diperhatikan oleh pihak Rumah Sakit Umum Bhakti Rahayu Surabaya untuk peningkatan mutu pelayanan rawat inap.

Konsumen yang datang ke rawat inap Rumah Sakit Umum Bhakti Rahayu Surabaya memiliki kepentingan yang berbeda-beda. Pelayanan yang sesuai dengan kepentingan konsumen akan menghasilkan kepuasan pasien. Hal ini sesuai dengan teori perspektif mutu pelayanan menurut Pohan (2006), yaitu konsumen melihat pelayanan kesehatan yang bermutu sebagai pelayanan yang dapat memenuhi kebutuhan konsumen yang dirasakan dan diselenggarakan dengan cara yang sopan dan santun, tepat waktu, tanggap dan mampu menyembuhkan keluhannya serta mencegah berkembangnya atau meluasnya penyakit. Pandangan konsumen ini sangat penting karena konsumen yang merasa puas akan mematuhi pengobatan dan mau datang kembali untuk melakukan pemeriksaan kesehatan sehingga dapat tercipta loyalitas pasien.

Tingkat Kepuasan Pasien Terhadap Pelayanan Rawat Inap di Rumah Sakit Umum Bhakti Rahayu Surabaya

Tingkat kepuasan pasien terhadap pelayanan rawat inap di Rumah Sakit Umum Bhakti Rahayu Surabaya disajikan pada Tabel 3 . 
Tabel 3 Uraian NilaiKepuasan Terendah Pada Customer Satisfaction Atribut Pelayanan Rawat Inap Rumah Sakit Umum Bhakti Rahayu Surabaya Tahun 2016

\begin{tabular}{|c|c|c|c|}
\hline \multirow[t]{2}{*}{ Atribut } & \multirow{2}{*}{$\begin{array}{c}\text { Uraian } \\
\text { Nilai Kepuasan Terendah }\end{array}$} & \multicolumn{2}{|c|}{ Customer Satisfaction } \\
\hline & & Kepuasan & GAP \\
\hline $\begin{array}{l}\text { Layanan Penerimaan } \\
\text { pasien/UGD }\end{array}$ & $\begin{array}{l}\text { Kecukupan kursi yang tersedia } \\
\text { diruang tunggu }\end{array}$ & 2,98 & $-1,11$ \\
\hline Ruang Rawat Inap & Pembatasan jam berkunjung & 2,29 & 1,79 \\
\hline Dokter & $\begin{array}{l}\text { Mengunjungi pasien dua kali sehari } \\
\text { dan berkomunikasi }\end{array}$ & 2,78 & $-1,43$ \\
\hline Perawat & Perawat memberi informasi & 4,19 & $-1,28$ \\
\hline Farmasi & $\begin{array}{l}\text { Kursi untuk keluarga pasien yang } \\
\text { menunggu }\end{array}$ & 4,06 & $-1,1$ \\
\hline Gizi & $\begin{array}{l}\text { Kebersihan peralatan makan yang } \\
\text { digunakan }\end{array}$ & 2,8 & -1.20 \\
\hline Administrasi & Penyediaan pembayaran non tunai & 2,97 & $-1,27$ \\
\hline
\end{tabular}

Kepuasan pasien adalah tanggapan pasien terhadap kesesuaian tingkat kepentingan atau harapan (ekspektasi) sebelum mereka menerima jasa pelayanan dengan sesudah pelayanan yang mereka terima (Muninjaya, 2011).Pada layanan penerimaan pasien atau UGD, nilai terendah uraian kepuasan terdapat pada kecukupan kursi yang tersedia untuk pasien dan keluarga yang sedang menunggu giliran layanan. Padahal terdapat beberapa dimensi mutu pelayanan pada kualitas jasa,salah satunya adalah kelengkapan sarana prasarana (Gasperz,2011).

Pada pelayanan ruang rawat inap yang memiliki nilai terendah ialah pembatasan jam berkunjung. Secara umum mean atau rataratakepuasan ruang rawat inap belum mencapai kategori puas.

Pada layanan dokter rawat inap mengunjungi pasien dua kali sehari dan berkomunikasi. Hal tersebut membuktikan bahwa aspek komunikasi interpersonal telah mencapai kepuasan pasien. Mudie \& Cottam (1999) dalam Tjiptono(2012),menyatakan bahwa umumnya pelanggan yang tidak puas terhadap kualitas layanan pada sebuah jasa disebabkan karena adanya ketidaksesuaian komunikasi antara pelanggan dan penyedia layanan. Maka, komunikasi antara pasien dan petugas perlu ditingkatkan.

Pada layanan perawat di ruang rawat inap aspek yang memiliki nilai paling rendah ialah perawat memberi informasi. Mengingat pelayanan keperawatan dalam sebuah pelayanan dirumah sakit memiliki peranan vital karena sebagian besar waktu pasien adalah bersama perawat. Maka kebutuhan pasien akan pelayanan keperawatan harus dipenuhi guna memenuhi kepuasan pasien.

Pada layanan farmasi layanan rawat inap, nilai kepuasan yang paling rendah ialah pada aspek kursi untuk keluarga pasien yang menunggu. Pada layanan gizi rawat inap, nilai kepuasan yang paling rendah pada aspek Kebersihan peralatan makan yang digunakan.Pada layanan Administrasi rawat inap, nilai kepuasan yang paling rendah terdapat pada aspek penyediaan pembayaran non tunai.

Apabila diklasifikasikan berdasarkan teori Donabedian (1979), maka keinginan pelanggan yang harus dipenuhi untuk mencapai kepuasan adalah pada aspek technical care yakni pada 
penyediaan sarana fisik yang lebih memadai dibandingkan dengan functional care dan amenity. Hal tersebut menunjukkan bahwa peningkatan fasilitas pada aspek fisik menjadi hal penting yang harus diperhatikan oleh pihak Rumah Sakit Umum Bhakti Rahayu Surabaya.

Secara umum, hasil penelitian menunjukkan bahwa Rumah Sakit Umum Bhakti Rahayu Surabaya belum memenuhi harapan pasienkarena pada GAP sebagian besar menunjukkan nilai negatif yang artinya harapan>kenyataan(Parasuraman et.al, 1988) dalam Tjiptono (1997). Harapan pelanggan dapat ditentukan oleh faktor umum yang meliputi kebutuhan pribadi, pengalaman masa lampau, rekomendasi dari mulut ke mulut, dan iklan.

Menurut Supriyanto dan Ernawaty (2010), pelanggan mempunyai harapan yang ditentukan pula oleh pengalaman dan tipe kepribadian. Harapan pelanggan yang dapat dipenuhi atau melampaui pelayanan akan menimbulkan kepuasan pasien. Demi mewujudkan pelayanan yang bermutu, maka kepuasan pasien harus tercapai yang mana akan menciptakan keuntungan bagi rumah sakit.

\section{Goal (Tujuan) Pelayanan Ruang Rawat Inap di Rumah Sakit Umum Bhakti Rahayu Surabaya.}

Goal adalah tujuan penentuan tingkat kepuasan yang ingin dicapai untuk setiap keinginan dan kebutuhan pelanggan (Cohen,1995), nilainya ditentukan oleh petugas manajemen rawat inap sebagai pemberi pelayanan. Goal merupakan sasaran perbaikan yang ingin dicapai oleh pihak manajemen berdasarkan kebutuhan dan keinginan konsumen, dalam hal ini pasien. Hasil penelitian menunjukkan goal pelayanan rawat inap Rumah Sakit Umum Bhakti Rahayu Surabaya sebagian besar masuk kategori puas dengan nial goal 3 . Terdapat 1 uraian dengan kategori sangat puas dengan nilai goal 4 yaitu kebersihan peralatan makan yang digunakan.

Hasil tersebut menunjukkan bahwa Rumah Sakit Umum Bhakti Rahayu Surabaya sebagai penyedia jasa pelayanan kesehatan telah berupaya memenuhi setiap keinginan dan kebutuhan pasien sebagai pelanggan dalam menciptakan mutu pelayanan yang baik. Pasien berhak mendapatkan pelayanan yang terbaik karena merupakan tujuan suatu penyedia pelayanan kesehatan, maka Rumah Sakit Umum Bhakti Rahayu Surabaya perlu meningkatkan mutu pelayanan.

Mutu pelayanan berpusat pada upaya pemenuhan kebutuhan dan keinginan pelanggan dan ketepatan penyampaiannya dalam mengimbangi harapan pelanggan. Terdapat dua faktor utama yang mempengaruhi mutu pelayanan yaitu pelayanan yang diharapkan dan yang dirasakan. Menurut Parasuraman et al, 1985 menyatakan bahwa baik tidaknya mutu pelayanan tergantung pada kemampuan penyedia jasa dalam memenuhi harapan pelanggan secara konsisten. Melalui peningkatan mutu pelayanan, akan memberikan kepuasan pasien akan mendapatkan pasien yang lebih banyak.

Sales Point (Nilai Jual) Pelayanan Ruang Rawat Inap di RumahSakit Umum Bhakti Rahayu Surabaya.

Sales pointadalah nilai jual yang dimiliki oleh sebuah produk berdasarkan seberapa baik 
kebutuhan pelanggan terpenuhi (Cohen, 1995), nilainya ditentukan oleh petugas manajemen rawat inap. Nilai sales point mencerminkan tingkat kepentingan yang dapat diperoleh apabila dilakukan kepentingan perbaikan dan penyempurnaan indikator.Hasil penelitian menunjukkan 16 uraian dengan nilai sales point 1,5 dimana tingkat yang dapat diperoleh Rumah Sakit Umum Bhakti Rahayu Surabaya apabila dilakukan perbaikan dan penyempurnaan indikator tinggi.Terdapat 15 uraian dengan nilai sales point 1,2 dimana tingkat yang dapat diperoleh Rumah Sakit Umum Bhakti Rahayu Surabaya apabila dilakukan perbaikan dan penyempurnaan indikator sedang.

Terdapat 4 uraian yang memiliki nilai sales point1 dimana tingkat yang dapat diperoleh Rumah Sakit Umum Bhakti Rahayu Surabaya apabila dilakukan perbaikan dan penyempurnaan indikator rendah yaitu kebersihan dan kerapian ruangan pada atribut pelayanan farmasi, petugas memberi informasi mengenai menu yang tersedia dan menanyakan kecukupan dan rasa makanan serta makanan yang disukai/ tidak disukai pasien pada atribut pelayanan gizi, dan pada atribut administrasi dan keuangan yaitu ruang administrasi nyaman, bersih, dan harum serta penyediaan pembayaran non tunai untuk memudahkan proses pembayaran.

Secara umum nilai sales point pelayanan rawat inap di Rumah Sakit Umum Bhakti Rahayu Surabaya sudah tinggi, namun perlu mendapatkan perhatian oleh Rumah Sakit Umum Bhakti Rahayu Surabaya agar dilakukan perbaikan dan penyempurnaan indikator. Mengingat pasien dalam memanfaatkan pelayanan kesehatan di era modern ini dengan cepat dapat mengetahui informasi. Informasi tersebut berdampak pada pengetahuan, cara pandang, sikap dan pola hidup sehingga menjadi lebih kritis. Dengan meningkatnya tingkat kritis masyarakat, keinginan dan harapan terhadap pelayanan kesehatan pelayanan kesehatan semakin meningkat (Arianto, 2011).

Nilai Improvement Ratio (IR) Pelayanan Rawat Inap di RumahSakit Umum Bhakti Rahayu Surabaya

Hasil penelitian menunjukan bahwa terdapat 6 atribut yang termasuk kategori moderate difficult improvement dan 7 atribut yang termasuk kategori difficult improvement. Kategori moderate difficult improvement memiliki arti perlu upaya sedang untuk perbaikan dalam mencapai kepuasan konsumen. Kategori difficult improvement memiliki arti perlu upaya keras untuk perbaikan dalam mencapai kepuasan konsumen.

Uraian yang termasuk kategori moderate difficult improvement adalah kecukupan kursi yang tersedia untuk pasien dan keluarga yang sedang menunggu giliran layanan pada atribut UGD/Penerimaan pasien, tempat tidur pasien telah disiapkan dalam keadaan rapi bersih dan siap pakai dan kecukupan dan kebersihan toilet yang tersedia untuk pasien atau anggota keluarga yang sedang menjaga pasien pada atribut ruang rawat inap, dokter mengunjungi pasien dua kali sehari, berkomunikasi dengan pasien dan perawat.

Dokter tersedia dalam 24 jam dan dokter yang menangani pasien selalu on call atau dapat dihubungi sewaktu-waktu pada atribut dokter rawat inap, perawat memberi informasi tentang peraturan, 
waktu makan, kunjungan dokter, penyimpanan barang berharga, dan sebagainya pada atribut perawat rawat inap, petugas melayani dengan sopan, ramah, dan tanggap dan kursi untuk keluarga pasien yang menunggu obat cukup tersedia pada atribut pelayanan farmasi, dan penyediaan fasilitas pembayaran non tunai (debet) untuk memudahkan proses pembayaran pada atribut pelayanan administrasi dan keuangan.

Uraian yang termasuk kategori difficult improvement adalah ruang rawat inap tertata rapi, bersih, tenang, aman, nyaman dan pembatasan jam berkunjung dan keluarga yang menjaga pasien pada atribut ruang rawat inap dan kebersihan peralatan makan yang digunakan pada atribut pelayanan gizi. Pihak Rumah Sakit Umum Bhakti Rahayu Surabaya seharusnya melakukan upaya peningkatan kebersihan peralatan makan yang digunakan atau melakukan pembaruan alat makan secara berkala.

Berdasarkan hasil penelitian, sebagian besar upaya perbaikan yang harus dilakukan oleh Rumah Sakit Umum Bhakti Rahayu Surabaya adalah pada aspek functional care dan amenity. Aspekfunctional care berkaitan dengan kualitas cara penyampaian suatu jasa berdasarkan penampilan fisik, kemampuan yang dapat memberi rasa aman terhadap pasien, kemampuan menumbuhkan kepercayaan, respons terhadap keluhan pasien dan cara berkomunikasi dengan pasien (Donabedian, 1996). Aspek amenity juga berkaitan dengan penampilan fisik dari fasilitas kesehatan, personil, dan peralatan medis maupun non medis (Donabedian, 1996).
Pihak Rumah Sakit Umum Bhakti Rahayu Surabaya harus melakukan perubahan dan terobosan apabila menginginkan adanya peningkatan mutu pelayanan di unit rawat inap. Pelayanan yang bermutu adalah pelayanan yang berfokus pada pelanggan yang akan meningkatkan kepuasan dan kepercayaan pasien terhadap citra Rumah Sakit (Gaspers, 2002). Pemberian pelayanan yang sesuai dengan harapan pasien dilakukan dengan memberikan respon teknis sesuai harapan pasien terhadap pelayanan rawat inap. Salah satu respon teknis yang dapat dilakukan yaitu pembenahan ruang rawat inap Rumah Sakit Umum Bhakti Rahayu Surabaya dimana akan menciptakan ruangan yang bersih, rapi, tenang, serta nyaman.

Planning Matrix Sebagai Upaya Peningkatan Mutu Pelayanan Rawat Inap Di Rumah Sakit Umum Bhakti Rahayu Surabaya

Planning matrix sebagai upaya peningkatan mutu pelayanan rawat inap di Rumah Sakit Umum Bhakti Rahayu Surabaya disusun berdasarkan completed planning matrixyang terdiri dari nilai raw weight (RW), normalized raw weight (NRW), dan cummulative normalized raw weight (CNRW).

Nilai raw weight diperolehberdasarkan perkalian antara tingkat kepentingan (importance to customer), nilai jual (sales point), dan rasio perbaikan (improvement ratio) sedangkan perhitungan normalized raw weight (NRW) diperoleh dari nilai raw weight dibagi dengan total raw weight dalam satu atribut.

Penghitungan cummulative normalized atribut (CNRW) merupakan penjumlahan dari 
normalized raw weight padasetiap atribut.

Berdasarkan nilai CNRW yang terbesar dapat dilihat bobot masalah pada sebuah atribut. Berikut adalah hasilperhitungan RW, NRW, dan CNRW setiap atribut.Urutan atribut pelayanan rawat inap yang perlu diprioritaskan untuk diperbaiki berdasarkan nilai NRW (normalized raw weight) yang paling tinggi. Adapun tabel planning matrix pelayanan rawat inap di Rumah Sakit Umum Bhakti Rahayu Surabaya Tahun 2016 disajikan pada tabel 4.

Berdasarkan tabel 4, dapat diketahui bahwa total nilai normalized raw weight (NRW) adalah sebesar 6,92 sehingga melebihi standar yakni nilai NRW sebesar 0 - 1. Hal tersebut menunjukkan bahwa mutu pelayanan rawat inap di Rumah Sakit Umum Bhakti Rahayu Surabaya belum memenuhi standar pelayanan yang baik. Oleh karena itu, perlu dilakukan peningkatan mutupelayanan rawat inap di Rumah Sakit Umum Bhakti Rahayu Surabaya untuk mencapai standar pelayanan yang baik.

Berdasarkan tabel 4, dapat diketahui bahwa nilai cummulative normalized weight (CNRW) tertinggi adalah pada atribut ruang rawat inap dan dokter rawat inap, oleh sebab itu kedua atribut tersebut perlu diprioritaskan sebagai upaya meningkatkan mutu rawat inap di Rumah Sakit Umum Bhakti Rahayu Surabaya. Nilai kepuasan pasien terendah ada pada atribut ruang rawat inap, maka perlu dilakukan pembenahan terkait dengan ruang rawat inap demi mewujudkan kepuasan pasien.

Tabel 4 Completed Planning Matrix Pelayanan Rawat Inap di Rumah Sakit Umum Bhakti Rahayu Surabaya Tahun 2016

\begin{tabular}{|c|c|c|c|c|}
\hline Atribut & Uraian & RW & NRW & CNRW \\
\hline \multirow{5}{*}{$\begin{array}{l}\text { Layanan } \\
\text { Penerimaan Pasien } \\
\text { IRNA/ UGD }\end{array}$} & $\begin{array}{l}\text { Petugas melayani pasien dengan sopan, ramah } \\
\text { dan tanggap }\end{array}$ & 1,47 & 0,08 & \multirow[t]{5}{*}{0,99} \\
\hline & $\begin{array}{l}\text { Petugas melayani pasien dengan cepat, tepat } \\
\text { dan tidak berbelit-belit }\end{array}$ & 5,76 & 0,30 & \\
\hline & $\begin{array}{l}\text { Kecukupan kursi yang tersedia untuk pasien dan } \\
\text { keluarga yang sedang menunggu giliran layanan }\end{array}$ & 2,42 & 0,13 & \\
\hline & $\begin{array}{l}\text { Kursi roda/troli tersedia untuk membawa pasien } \\
\text { ke ruang rawat inap }\end{array}$ & 3,53 & 0,19 & \\
\hline & $\begin{array}{l}\text { Kelengkapan dan kebersihan peralatan yang } \\
\text { dipakai }\end{array}$ & 5,70 & 0,29 & \\
\hline \multirow{5}{*}{ Ruang Rawat Inap } & $\begin{array}{l}\text { Tempat tidur pasien telah disiapkan dalam } \\
\text { keadaan rapi bersih dan siap pakai }\end{array}$ & 7,89 & 0,35 & \multirow{5}{*}{1,00} \\
\hline & $\begin{array}{l}\text { Ruang rawat inap tertata rapi, bersih, tenang, } \\
\text { aman dan nyaman }\end{array}$ & 1,83 & 0,08 & \\
\hline & $\begin{array}{l}\text { Pembatasan jam berkunjung dan keluarga yang } \\
\text { menjaga pasien }\end{array}$ & 3,14 & 0,14 & \\
\hline & $\begin{array}{l}\text { Kecukupan kursi yang tersedia untuk anggota } \\
\text { keluarga yang sedang menjaga pasien }\end{array}$ & 4,71 & 0,21 & \\
\hline & $\begin{array}{l}\text { Kecukupan dan kebersihan toilet yang tersedia } \\
\text { untuk pasien atau anggota keluarga yang sedang } \\
\text { menjaga pasien }\end{array}$ & 4,98 & 0,22 & \\
\hline \multirow{3}{*}{$\begin{array}{l}\text { Dokter Ruang } \\
\text { Rawat Inap }\end{array}$} & $\begin{array}{l}\text { Doktermengunjungi pasien dua kali sehari dan } \\
\text { berkomunikasi dengan pasien dan perawat }\end{array}$ & 3,24 & 0,16 & \\
\hline & $\begin{array}{l}\text { Doktermelayani pasien dengan ramah, sopan } \\
\text { dan tanggap }\end{array}$ & 5,41 & 0,26 & \\
\hline & $\begin{array}{l}\text { Dokter selalu menanyakan perubahan kondisi } \\
\text { pasien dan jika perlu mengganti obat }\end{array}$ & 3,99 & 0,19 & \\
\hline
\end{tabular}




\begin{tabular}{|c|c|c|c|c|}
\hline Atribut & Uraian & RW & NRW & CNRW \\
\hline & $\begin{array}{l}\text { Dokterselalu memberikan kesempatan bertanya } \\
\text { kepada pasien }\end{array}$ & 7,12 & 0,34 & \\
\hline & $\begin{array}{l}\text { Dokter tersedia dalam } 24 \text { jam dan dokter yang } \\
\text { menangani pasien selalu on call }\end{array}$ & 1,00 & 0,05 & 1,00 \\
\hline \multirow{5}{*}{$\begin{array}{l}\text { Perawat } \\
\text { Ruang Rawat Inap }\end{array}$} & $\begin{array}{l}\text { Penampilan perawat yang bertugas rapi, bersih } \\
\text { dan bersikap mau menolong }\end{array}$ & 5,88 & 0,27 & \multirow{5}{*}{0,99} \\
\hline & $\begin{array}{l}\text { Perawat melayani pasien dengan ramah, sopan } \\
\text { dan tanggap }\end{array}$ & 4,23 & 0,19 & \\
\hline & $\begin{array}{l}\text { Perawat memperhatikan kebutuhan dan keluhan } \\
\text { pasien }\end{array}$ & 1,37 & 0,06 & \\
\hline & $\begin{array}{l}\text { Perawat memberi informasi tentang peraturan, } \\
\text { waktu makan, kunjungan dokter, penyimpanan } \\
\text { barang berharga, dll }\end{array}$ & 3,09 & 0,14 & \\
\hline & $\begin{array}{l}\text { Perawat selalu memberi obat pasien sesuai } \\
\text { dengan prosedur pemberian obat }\end{array}$ & 7,20 & 0,33 & \\
\hline \multirow{5}{*}{ Pelayanan Farmasi } & Waktu tunggu layanan farmasi $<30$ menit & 2,35 & 0,14 & \multirow{5}{*}{0,98} \\
\hline & Kebersihan dan kerapian ruangan & 4,90 & 0,29 & \\
\hline & Kecepatan petugas dalam melayani pasien & 4,66 & 0,27 & \\
\hline & $\begin{array}{l}\text { Petugas melayani dengan sopan, ramah, dan } \\
\text { tanggap }\end{array}$ & 1,20 & 0,07 & \\
\hline & $\begin{array}{l}\text { Kursi untuk pasien yang menunggu obat cukup } \\
\text { tersedia }\end{array}$ & 3,63 & 0,21 & \\
\hline \multirow{5}{*}{ Pelayanan Gizi } & $\begin{array}{l}\text { Petugas memberi informasi mengenai menu yang } \\
\text { tersedia dan menanyakan kecukupan dan rasa } \\
\text { makanan serta makanan yang disukai/ tidak } \\
\text { disukai pasien }\end{array}$ & 0,99 & 0,05 & \multirow{5}{*}{0,98} \\
\hline & $\begin{array}{l}\text { Petugas selalu tepat waktu dalam memberikan } \\
\text { menu makanan }\end{array}$ & 3,10 & 0,17 & \\
\hline & Keramahan petugas saat melayani pasien & 5,82 & 0,32 & \\
\hline & Penyediaan menu makanan yang bervariasi & 4,61 & 0,25 & \\
\hline & Kebersihan peralatan makan yang digunakan & 3,43 & 0,19 & \\
\hline \multirow{5}{*}{$\begin{array}{l}\text { Administrasi dan } \\
\text { Keuangan }\end{array}$} & Ketepatan informasi biaya & 5,58 & 0,35 & \multirow{5}{*}{0,98} \\
\hline & $\begin{array}{l}\text { Petugas administrasi dan keuangan melayani } \\
\text { pasien dengan ramah }\end{array}$ & 4,42 & 0,28 & \\
\hline & Ruang administrasi nyaman, bersih, dan harum & 1,86 & 0,11 & \\
\hline & $\begin{array}{l}\text { Penyediaan fasilitas pembayaran non tunai } \\
\text { (debet) untuk memudahkan proses pembayaran }\end{array}$ & 0,67 & 0,04 & \\
\hline & Proses pembayaran $<1$ jam & 3,20 & 0,20 & \\
\hline & Total & & 6,92 & \\
\hline
\end{tabular}

Keterangan: RW = Raw Weight; NRW = Normalized Raw Weight; CNRW = Cummulative Normalized Raw Weight

Adanya kepuasan dan mutu pelayanan rawat inap yang baik dapat memberikan manfaat bagi Rumah Sakit Umum Bhakti Rahayu Surabaya yaitu terciptanya loyalitas pelanggan, membentuk komunikasi berantai (word of mouth), meningkatkan citra rumah sakit, meningkatkan laba rumah sakit, dan terjalin hubungan yang harmonis antara pelanggan dan rumah sakit (Tjiptono, 2000).

\section{SIMPULAN}

Tingkat kepentingan pasien tertinggi pada aspek kualitas fungsional (functional quality) terkait proses menyampaikan pelayanan, bagaimana petugas dapat melayani pasien dengan baik, serta kenyamanan. Tingkat kepuasan pasien terhadap pelayanan rawat inap di Rumah Sakit Umum Bhakti Rahayu Surabaya belum memenuhi harapan pasien. Demi mewujudkan pelayanan yang bermutu, maka kepuasan pasien harus tercapai dalam meningkatkan loyalitas pasien. 
Goal pelayanan rawat inap di Rumah Sakit Umum Bhakti Rahayu Surabaya sebagian besar masuk pada kategori puas. Nilai sales point pada pelayanan rawat inap di Rumah Sakit Umum Bhakti Rahayu Surabaya sebagian besar masuk kategori sales pointtinggi. Improvement ratio pelayanan rawat inap di Rumah Sakit Umum Bhakti Rahayu Surabaya sebagian besar termasuk dalam dua kategori yaitu moderate difficult improvement dimana membutuhkan upaya sedang untuk perbaikan dalam mencapai kepuasan konsumen.

Nilai raw weight (RW), normalized raw weight (NRW), dan cummulative normalized raw weight(CNRW) pelayanan rawat inap di Rumah Sakit Umum Bhakti Rahayu Surabaya tertinggi ada pada atribut ruang rawat inap dan dokter rawat inap. Kedua atribut tersebut perlu diprioritaskan untuk dilakukan perbaikan sebagai upaya peningkatan mutu pelayanan rawat inap di Rumah Sakit Umum Bhakti Rahayu Surabaya.

\section{DAFTAR PUSTAKA}

Aditama, Tjandra Y. (2003). Manajemen Administrasi Rumah Sakit. Jakarta: Universitas Indonesia Press.

Arianto, Wahyu L. (2011). PerencanaanPeningkatanMutuLayanan BerdasarMetodeHouseofQuality.Jurnal Administrasi Kebijakan dan Kesehatan, 9 (2): pp.104-112.

Cohen,L.(1995).QualityFunctionDeployment:Howto MakeQFDWork YoubyDonClausing. Massachusetts: Addyson-Wesley Publishing Company.

Departemen Kesehatan Republik Indonesia. 2005. Buku Petunjuk Pengisian, Pengolahan dan Penyajian Data Rumah Sakit. Jakarta: Depkes RI

Donabedian, A. (1979). The Quality of Medical Care: A Concept In Search Of A Definition. J Fam. Pract, 9(2): pp.84-277.

Donabedian A. (1996). The Effectiveness of Quality Health Care. International Journal of Quality Health Care, 8 ( 4): pp. 401-407.

Gasperz,V.(2011). Manajemen Kualitas dalam
Industri Jasa. Jakarta: PT. Gramedia Pustaka Utama

Gasperz,V.(2011).Tota/QualityManagement(TQM)U ntukPraktisilndustri.Jakarta: PT.PercetakanPenebarSwadaya.

Muninjaya, A.A. Gde. (2011). Manajemen Mutu Pelayanan Kesehatan. Jakarta: Buku Kedokteran EGC

Parasuraman, A., Zethaml,V. A. And Berry, L.L (1985). A Conceptual Model of Service Quality and Its Implications For Future Research. Journal of Marketing, 49: pp. 4250.

Parasuraman, A., Zethaml,V. A. And Berry, L.L (1988). SERVQUAL: A Multiple-Item Scale for Measuring Consumer Perceptions of Service Quality. Journal of Retailing, 64(1): pp. 12-40.

Pohan. S. (2006). Jaminan MutuLayananKesehatan. Jakarta: Buku KedokteranECG.

Supriyanto, Stefanus dan Ernawaty. (2010). Pemasaran Industri Jasa Kesehatan. Yogyakarta: Penerbit Andi.

Tjptono, F. (1997). Prinsip-prinsip Total Quality service. Edisi 3. Yogyakarta: Penerbit Andi.

Tjptono, F. (2000). Manajemen Jasa. Yogyakarta: Penerbit Andi.

Tjiptono, F. (2012). Service Management Mewujudkan Layanan Prima. Yogyakarta: Penerbit Andi.

Undang-Undang Republik Indonesia Nomor 44 Tahun 2009 Tentang Perumahsakitan. Jakarta. 